\title{
Seasonal variation in the planktonic diversity of Tumaria reservoir of Kashipur Uttarakhand India
}

\author{
Shyam R. ${ }^{1}$ 凶, Kumar P. ${ }^{2}$ and Badola S. $^{3}$
}

Received: 13.09.2020

Revised: 14.10 .2020

Accepted: 09.11.2020

\begin{abstract}
Plankton are the microscopic plants and animals found in any aquatic ecosystem. Phytoplankton are microscopic plants while zooplankton are microscopic animals. The present investigation was carried out to find out the planktonic diversity of the Tumaria reservoir during January-December 2018. To fulfill the objectives of the present study, samples were collected from Tumaria reservoir on monthly basis. The samples were analysed for various physicochemical parameters (temperature, transparency, TDS, TS, pH, DO and chloride) and planktonic diversity. During the present study phytoplankton and zooplankton were identified under the microscope with the help of standard photographs following standard reference materials. During course of study phytoplankton was observed were Chlorophyceae $(50 \%)>$ Bacillariophyceae $(37 \%)>$ Cyanophyceae $(13 \%)$ while zooplankton observed were Rotifera $(40 \%)>$ Protozoa $(34 \%)>$ Cladocera (23\%) $>$ Copepod $(3 \%)$. It was also found that plankton diversity was found higher during the winter months followed by summer and minimum during the monsoon months. Planktonic diversity observed during study was found strongly correlated with temp $(r=\mathbf{- 0 . 5 6})$ and transparency $(r=0.95)$.
\end{abstract}

Key Words: Chlorophyceae, Phytoplankton, Tumaria reservoir, Zooplankton

\section{Introduction}

Plankton are the microscopic milieu of aquatic ecosystem. Phytoplankton are the producers of aquatic ecosystem as they store sun energy and supply the energy to higher trophic level. They make their own food by the process of photosynthesis. They provide food to zooplankton, fishes and other higher organisms in aquatic reservoir. Plankton are the most sensitive to water pollution. Any small change in the physicochemical or microbiological properties of water affects the planktonic diversity significantly (Summerwar, 2012). Tumaria reservoir possesses the variety and variability of plankton and fishes. Plankton stands on the base of food chain in reservoir. Plankton in any aquatic ecosystem is the indicator of the health of the system. Main Tumaria reservoir was constructed in the year 1961-1962 and its extension reservoir in the year 1969-1970. The reservoir is more or less rectangular in shape with very irregular shoreline. The Author's Address

${ }^{1}$ Department of Zoology Givernment Degree College, Jainti Almora, Uttarakhand

${ }^{2}$ Department of Zoology Government (P.G.) College, Nainidanda, Uttarakhand

${ }^{3}$ Department of Zoology Government (P.G.) College, Kotdwara, Uttarakhand

E-mail.: radhey.8088@gmail.com height of the reservoir is about 25 meter and it has 6 meter wide road.The upstream slope of the earthen dam is covered by pitching with heavy stones. The earthen portion of the dam is made up of locally available impervious and semipervious soil, slope is provided with good turf. The spillway of reservoir is developed by the stones and cement. It is designed to allow 14386 cusec of maximum flood water discharge. Reservoir has maximum breadth of about $4.5 \mathrm{~km}$ and length of about $10 \mathrm{~km}$. The basin of the reservoir is more or less conical in shape. It has approx. 15 meter depth in some places. The catchment area of the reservoir is 404sq.km. The spread area of the reservoir at FRL is 27 sq.k. The total capacity of the Tumaria reservoir is 165.54 and 167.75 million cubic meter at FRL and MRL, respectively. All the tributaries of the feeder river originate from Shivalik range and receive a numerous of rivulets in the course of their flow from north to south. The characteristics feature of the reservoir is hilly. Approximately 25\% of the catchment area is used for agriculture and rest of the area $(75 \%)$ is very rich in dense natural forest. On account of denudation of the forest in catchment areas, soil erosion has assumed enormous areas. In Tumaria reservoir, the first 


\section{Shyam et al.}

sedimentation survey was carried out by the IRI, Roorkee in 1989. The low capacity of the reservoir is 1.66 million cubic meter during the last two decades. The sedimentation index has been found to be 4.57 ha m. per year per 100 sq. km (Agarwal, 1989).

Water of the Tumaria reservoir is mainly used for the irrigation purpose. Four canals are constructed from this reservoir namely: Tumaria canal, Tumaria Phika feeder, Tumaria extension canal and Tumaria escape canal. With the help of irrigation facilities from Tumaria reservoir, the agricultural fields of the surrounding areas are capable of producing three different major crops in a year I.e paddy farming, wheat farming and sugarcane farming. The water level of the Tumaria reservoir is heavily influenced by the seasonal flood during month of July, August and September. No systematic work has been carried out in Tumaria reservoir regarding planktonic diversity. Therefore in the present study an attempt has been made to find out the status of diversity of plankton of the Tumaria reservoir of Udham Singh Nagar.

\section{Material and Methods}

The samples of water and plankton were collected from the Tumaria reservoir on monthly basis starting from January 2018 to December 2018. Approx. 100 litres of water samples was filtered through plankton net for the collection of plankton's sample. The residue left in the net was collected in a bottle and preserved with 4\% formalin. The identifications of the plankton were made by the standard methods prescribed in APHA (1995) and Edmondson (1959). During the present study phytoplankton and zooplankton were identified under the microscope. Water quality was also analysed using the standard methods prescribed in APHA (1995) and Khanna and Bhutiani (2007).

\section{Results and Discussion}

The results of phytoplankton diversity are given in table 1 and fig 1 . Total numbers of 30 genera of phytoplankton were encountered during the study. Major share of phytoplankton diversity is accounted by Chlorophyceae (green algae) represented by 15 genera (Ankistrodesmus, Chlamydomonas, Cladophora, Closterium, Comarium Cosmarium, Euglena, Oedogonium, Pandorina, Pediastrum,
Spirogyra, Tetraspora, Ulothrix, Uronema and Volvox) followed by Bacillariophyceae (diatoms) which is brown algae, second major group in terms of contribution in phytoplanktonic diversity, represented by 11 genera (Amphora, Bacillaria, Cyclotella, Cymbella, Denticula, Diatoma, Fragilaria, Frustulia, Gomphoneis, Naviculam and Nitzschia) followed by the blue green algae (Cyanophyceae) which constituted only 04 genera (Anabaena, Nostoc, Spirulina, Ocillatoria). Temperature is responsible for distribution of plankton and other species. It also affects metabolic rates of the aquatic milieu. During the study period the lowest value of temperature $\left(16.9^{\circ} \mathrm{C}\right)$ was observed in the month of January and highest value of temperature was observed in the month of June $\left(30.6^{0} \mathrm{C}\right)$.

During our observations the maximum diversity was recorded during the winter months showing the negative correlation with temperature $(\mathrm{r}=-0.56)$. Similar pattern was observed by Bhadula and Joshi (2012) and Khanna et al. (1998). Sharma and Tiwari (2018) also observed that phytoplankton diversity is certainly depends on water quality. Seasonal qualitative composition of phytoplankton diversity at four spots (Patrampur, Jagdishwala, Tumaria main canal and Kilabli) in the Tumaria reservoir during 2018 has been depicted in Table-1. During the study period (January, 2018 to December, 2018), the maximum genera of phytoplankton were recorded in the winter months and minimum was in the monsoon months. The Chlorophyceae were dominant over bacillariophycae and Cyanophyceae while Joshi et al. (1993) have observed that bacillariophycae were dominant over Chlorophyceae and Cyanophyceae in Ganga river.Zooplankton makes a significant link in food web operating in aquatic ecosystems. Zooplankton depends on phytoplankton and provides food to higher organisms in aquatic ecosystems. Therefore a study on qualitative estimation on zooplankton is the fundamental step to estimate quality and production status of aquatic ecosystems. Fisheries also depend on variety and diversity of zooplankton.

The zooplankton assemblage of Tumaria reservoir was assessed to provide base line information on an aspect of the biological characteristics of the river necessary for fishes, biodiversity conservation and reservoir management. Results are given in table 2 and fig 2. During the study period, $40 \%$ of total zooplankton diversity was accounted by four groups and twelve genera of Rotifera (Anura, Asplanchna, Brachionus, Filinia, 
Seasonal variation in the planktonic diversity of Tumaria reservoir

Table 1. Seasonal phytoplankton diversity of Tumaria reservoir during 2018

\begin{tabular}{|c|c|c|c|c|c|c|c|c|c|c|c|c|}
\hline \multirow[t]{3}{*}{ Genera } & \multicolumn{4}{|c|}{ Winter season } & \multicolumn{4}{|c|}{ Summer season } & \multicolumn{4}{|c|}{ Rainy season } \\
\hline & Jan. & Feb. & Dec. & Nov. & March & April & May & June & July & August & Sept. & Oct. \\
\hline & \multicolumn{12}{|c|}{ Chlorophyceae } \\
\hline Ankistrodesmus & + & + & + & + & + & + & + & + & + & - & + & + \\
\hline Chlamydomonas & + & + & + & + & + & + & + & + & + & + & + & + \\
\hline Cladophora & + & + & + & - & - & + & + & + & + & + & - & + \\
\hline Closterium & + & + & + & - & - & + & + & - & - & - & + & + \\
\hline Comarium & + & + & + & + & - & + & + & + & - & - & + & - \\
\hline Cosmarium & + & + & + & - & - & + & + & + & + & + & - & + \\
\hline Euglena & + & + & + & + & - & + & + & + & - & - & + & - \\
\hline Oedogonium & - & + & + & + & + & - & + & + & + & + & + & + \\
\hline Pandorina & + & + & + & + & + & + & + & - & + & + & - & + \\
\hline Pediastrum & + & + & - & + & - & + & - & - & + & + & - & + \\
\hline Spirogyra & + & + & + & + & + & + & + & + & + & + & + & + \\
\hline Tetraspora & - & + & + & + & + & - & - & - & + & + & + & + \\
\hline Ulothrix & + & + & + & + & + & + & + & + & + & - & + & + \\
\hline Uronema & - & + & + & + & + & + & + & - & + & + & + & + \\
\hline Volvox & + & + & + & + & - & + & + & + & - & - & + & - \\
\hline \multicolumn{13}{|c|}{ Bacillariophyceae } \\
\hline Amphora & + & + & + & + & + & + & + & + & + & + & + & + \\
\hline Bacillaria & + & + & + & - & + & + & + & - & - & + & + & + \\
\hline Cyclotella & + & + & + & + & + & + & + & + & - & + & + & - \\
\hline Cymbella & + & + & + & + & + & + & + & + & + & + & - & + \\
\hline Denticula & + & + & + & - & + & + & + & + & + & + & + & + \\
\hline Diatoma & + & + & + & + & + & + & + & + & - & - & + & - \\
\hline Fragilaria & + & + & + & + & + & + & + & + & + & - & - & + \\
\hline Frustulia & + & + & + & + & + & + & + & - & + & + & - & + \\
\hline Gomphoneis & + & + & + & + & + & + & - & - & + & - & - & + \\
\hline Navicula & + & + & + & - & + & + & + & + & + & - & + & + \\
\hline Nitzschia & + & + & + & + & + & + & + & + & + & + & + & + \\
\hline \multicolumn{13}{|c|}{ Cyanophyceae } \\
\hline Anabaena, & + & + & + & + & + & + & + & + & + & - & + & - \\
\hline Nostoc & + & + & + & + & - & + & + & + & - & - & - & - \\
\hline Spirulina & + & + & + & + & + & + & + & + & - & - & + & - \\
\hline Ocillatoria & + & + & + & + & + & + & + & - & - & + & - & + \\
\hline
\end{tabular}

(+) Present (-) Absent

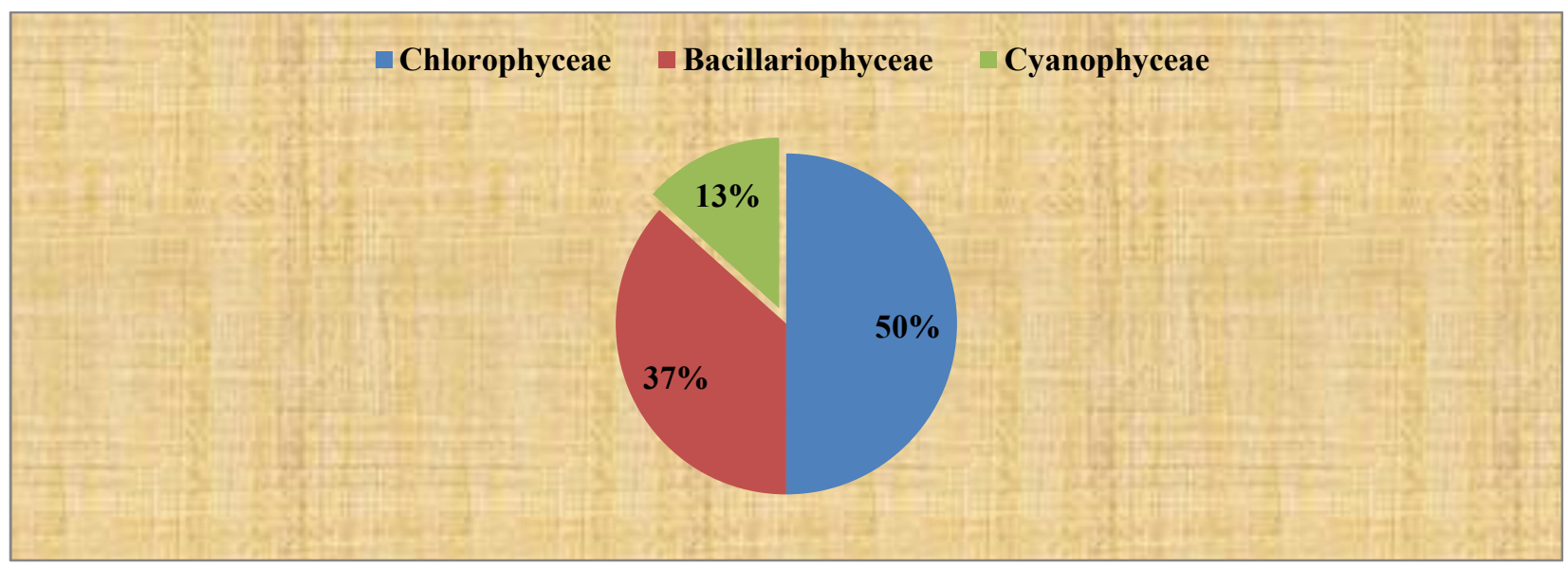

Fig 1. Showing phytoplankton diversity in Tumaria reservoir during 2018

Environment Conservation Journal 
Shyam et al.

Table 2. Seasonal Zooplanktonic diversity of Tumaria reservoir during 2018

\begin{tabular}{|c|c|c|c|c|c|c|c|c|c|c|c|c|}
\hline \multirow[t]{3}{*}{ Genera } & \multicolumn{4}{|c|}{ Winter season } & \multicolumn{4}{|c|}{ Summer season } & \multicolumn{4}{|c|}{ Rainy season } \\
\hline & Jan. & Feb. & Nov & Dec. & March & April & May & June & July & August & Sept. & Oct. \\
\hline & \multicolumn{12}{|c|}{ Rotifera } \\
\hline Anura & + & + & + & + & + & + & + & + & + & + & - & - \\
\hline Asplanchna & + & + & + & + & + & + & + & - & - & - & - & - \\
\hline Brachionus & + & + & + & + & + & + & - & - & - & - & - & - \\
\hline Filinia & + & + & + & + & + & + & + & + & + & + & + & + \\
\hline Keratella & + & + & + & + & + & + & + & + & + & - & - & - \\
\hline Lecane & + & + & - & - & - & + & - & - & - & - & - & + \\
\hline Monostyla & + & - & + & + & + & + & + & + & + & + & + & + \\
\hline Notholca & + & + & + & + & + & + & - & + & + & - & - & + \\
\hline Philodina & + & + & + & + & + & + & + & - & - & - & - & + \\
\hline Polyarthra & + & + & + & + & + & + & - & - & - & - & - & + \\
\hline Rotaria & + & + & + & - & + & + & + & + & + & + & + & + \\
\hline Trichocera & + & + & - & + & - & + & + & + & + & - & - & - \\
\hline \multicolumn{13}{|c|}{ Protozoa } \\
\hline Arcella & + & + & - & - & + & + & + & + & + & + & - & + \\
\hline Centrophyxis & + & + & - & - & + & + & + & + & + & + & - & + \\
\hline Didinium & + & + & - & + & + & + & + & + & - & + & - & + \\
\hline Difflugia & + & + & + & - & + & + & + & - & + & + & - & + \\
\hline Noctiluca & + & + & + & + & + & + & + & + & + & + & - & + \\
\hline Paramecium & + & + & + & + & + & + & + & + & + & + & - & + \\
\hline Spathidium & + & + & + & + & + & + & + & + & - & + & - & + \\
\hline Stentor & + & + & + & + & + & + & + & + & + & + & - & + \\
\hline Vorticella & + & + & + & + & + & + & + & + & + & + & - & + \\
\hline Volvox & + & + & - & - & + & + & + & + & + & + & + & + \\
\hline \multicolumn{13}{|c|}{ Cladocera } \\
\hline Bosmia & + & + & + & + & + & + & + & - & + & + & + & - \\
\hline Ceriodaphnia & + & + & + & + & + & + & + & + & - & - & - & + \\
\hline Chydorus & + & + & + & + & + & + & + & + & + & - & + & - \\
\hline Daphnia & + & + & + & + & + & + & + & + & + & + & + & + \\
\hline Diphanosoma & + & + & + & + & + & + & - & - & + & + & - & - \\
\hline Moina & + & + & - & - & + & + & + & - & + & + & - & + \\
\hline Simocephalus & + & + & + & + & + & + & + & + & + & + & + & + \\
\hline \multicolumn{13}{|c|}{ Copepoda } \\
\hline Cyclops & + & + & + & + & + & + & + & - & + & + & - & - \\
\hline
\end{tabular}

(+) Present (-) Absent

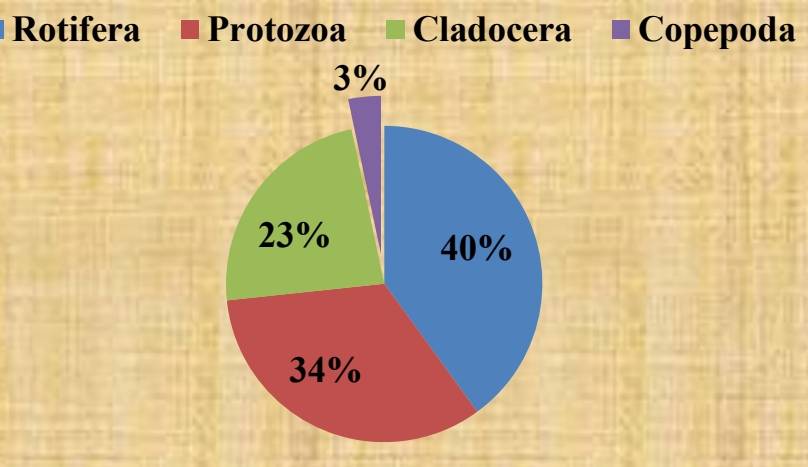

Fig 2. Showing Zooplankton diversity in Tumaria reservoir during 2018 
Keratella, Lecane, Monostyla, Notholca, Philodina, Polyarthra, Rotaria and Trichocera). A total of $34 \%$ of total zooplankton diversity was accounted by ten genera of Protozoa (Arcella, Centrophyxis, Didinium, Difflugia, Noctiluca, Paramecium, Spathidium, Stentor, Vorticella and Volvox). Seven genera of Cladocera (Bosmia, Ceriodaphnia, Chydorus, Daphnia, Diphanosoma, Moina and Simocephalus) were also identified accounted to about $23 \%$ of total zooplankton diversity. One genera of copepoda (Cyclops) also identified during the study accounted to about $3 \%$ of total zooplankton diversity. Negi and Pant (1983) observed rotifers as dominant group of zooplankton in Khurpatal lake. Undesirable changes in hydrobiological factors of reservoirs may create an unpleasant environment to the aquatic milieu (Khanna et al., 2011; Oriola, 2003). Zooplankton are important communities for the fisheries development (Pathani and Upadhyay, 2003). During present study it was found that most of the zooplankton diversity was higher during the winter months followed by summer months followed by monsoon months. Our results were supported by observations of several researchers (Sivakumar and Altaff, 2003; Khanna and Bhutiani, 2005; Negi et al. 2013 Singh, 2015; Rao, 2017; Major et al. 2017; Kumar and Shyam. 2018; Bhutiani et al. 2018a; Bhutiani et al. 2018b).

\section{Water Quality and Plankton diversity}

Water samples were analysed for various physicochemical parameters such as temperature, total solids, transparency, $\mathrm{pH}$, dissolved oxygen and chlorides. The water quality parameters are presented in Table 3 . In the present study the lower value of temperature $\left(16.9^{\circ} \mathrm{C}\right)$ was noted in the month of January and highest value of temperature $\left(30.6^{\circ} \mathrm{C}\right)$ was noted in the month of June, respectively. Total dissolved solids are solids which are dissolved in water. The total dissolved solids showed negative correlation with plankton diversity as it reduces the sunlight penetration in aquatic bodies.

Table 3. Showing mean values of physicochemical parameters of Tumaria reservoir

\begin{tabular}{|c|c|c|c|c|c|c|c|}
\hline \multirow{2}{*}{\multicolumn{8}{|c|}{ Parameters }} \\
\hline & & & & & & & \\
\hline Season & Months & $\begin{array}{l}\text { lemp. } \\
\left({ }^{\circ} \mathrm{C}\right)\end{array}$ & TDS (mg/l) & Trans. (cm) & $\mathbf{p H}$ & $\begin{array}{l}\text { DU } \\
(\mathrm{mg} / \mathrm{l})\end{array}$ & Cl (mg/l) \\
\hline \multirow[t]{4}{*}{ Winter } & January & $16.9 \pm 0.7$ & $95.6 \pm 0.8$ & $14.56 \pm 0.12$ & $8.1 \pm 0.23$ & $8.2 \pm 0.21$ & $10.27 \pm 0.17$ \\
\hline & February & $18.9 \pm 0.8$ & $97.3 \pm 1.78$ & $12.42 \pm 0.10$ & $7.9 \pm 0.12$ & $8.1 \pm 0.17$ & $12.42 \pm 0.19$ \\
\hline & November & $18.1 \pm 0.7$ & $101.37 \pm 0.89$ & $8.45 \pm 0.42$ & $7.8 \pm 0.21$ & $7.1 \pm 0.27$ & $14.18 \pm 0.26$ \\
\hline & December & $17.6 \pm 0.6$ & $99.2 \pm 0.81$ & $12.67 \pm 0.38$ & $8.0 \pm 0.20$ & $7.7 \pm 0.27$ & $13.27 \pm 0.17$ \\
\hline \multirow[t]{4}{*}{ Summer } & March & $22.1 \pm 0.3$ & $103.45 \pm 1.20$ & $10.45 \pm 0.37$ & $7.7 \pm 0.34$ & $7.7 \pm 0.18$ & $14.37 \pm 0.25$ \\
\hline & April & $25.2 \pm 0.4$ & $109.8 \pm 1.24$ & $9.27 \pm 0.21$ & $7.6 \pm 0.21$ & $7.5 \pm 0.18$ & $17.29 \pm 0.19$ \\
\hline & May & $29.1 \pm 0.3$ & $112.4 \pm 1.31$ & $8.28 \pm 0.32$ & $7.6 \pm 0.23$ & $7.2 \pm 0.15$ & $18.12 \pm 0.81$ \\
\hline & June & $30.6 \pm 0.7$ & $210.2 \pm 1.56$ & $8.20 \pm 0.78$ & $7.5 \pm 0.32$ & $5.5 \pm 0.16$ & $21.27 \pm 0.18$ \\
\hline \multirow[t]{4}{*}{ Rainy } & July & $30.1 \pm 0.8$ & $310.7 \pm 1.61$ & $4.27 \pm 0.98$ & $7.6 \pm 0.33$ & $5.7 \pm 0.18$ & $25.34 \pm 0.17$ \\
\hline & August & $29.1 \pm 0.7$ & $215.4 \pm 1.45$ & $4.89 \pm 0.87$ & $7.8 \pm 0.15$ & $6.1 \pm 0.18$ & $24.16 \pm 0.16$ \\
\hline & September & $25.5 \pm 0.5$ & $110.2 \pm 1.21$ & $6.54 \pm 0.67$ & $7.9 \pm 0.16$ & $6.5 \pm 0.22$ & $19.16 \pm 0.18$ \\
\hline & October & $20.2 \pm 0.6$ & $105.7 \pm 0.98$ & $6.02 \pm 0.56$ & $7.9 \pm 0.20$ & $6.7 \pm 0.25$ & $17.19 \pm 0.16$ \\
\hline
\end{tabular}


During the study period the lowest value of total dissolved solids $(95.6 \mathrm{mg} / \mathrm{l})$ was observed in the month of January and highest value of TDS $(310.7 \mathrm{mg} / \mathrm{l})$ was observed in the month of July. Similar results of TDS were observed by Bhutiani et al. (2018a) and Bhutiani et al. (2018b). Major et al. (2017) also observed similar patterns of phytoplankton in relation to TDS. Negi et al. (2013) also supports our results. The lowest value of $\mathrm{pH}$ was observed 7.5 during the month of June and highest value of $\mathrm{pH}$ was recorded as 8.1 during the month of January. During the study period, the lowest and highest values of dissolved oxygen were observed as $5.5 \mathrm{mg} / 1$ and $8.1 \mathrm{mg} / 1$ during the month of June and January. In the present the lowest and highest values of chlorides were recorded 10.27 $\mathrm{mg} / \mathrm{l}$ and $25.34 \mathrm{mg} / \mathrm{l}$ during the month of January and July, respectively. The lowest and highest values of transparency were noted $4.27 \mathrm{~cm}$ and $14.56 \mathrm{~cm}$ in the month of July and January, respectively. The transparency showed positive correlation $(\mathrm{r}=0.95)$ with plankton diversity.

\section{References}

Agarwal, C. K. 1989. Sedimentation survey of Tumaria reservoir. U.P. Irrigation Research Institute Roorkee (India), reserch Report No. T.M. Number 60 R.R. (H2-5): $1-9$.

APHA, 1995. Standard Method for Examination of water waste water. $20^{\text {th }}$ edition, American Public Health Association Washington D.C.

Bhadula, S. and Joshi, B. D. 2012. Studies on Phytoplanktonic Diversity of River Ganga, Within Haridwar City, Uttarakhand. Journal of Environment and Bio-Sciences, 26(1): 139-141.

Bhutiani R., Khanna, D. R., Ahamad, F. and Tyagi, V. 2018b. Assessment of water quality status of Malin river at Najibabad, Bijnor (UP), Water biology, (ISBN-978-935056-888-0): 281-307.

Bhutiani, R., Khanna, D. R., Malik, R., Ahamad, F. and Tyagi, V. 2018a. Physico-Chemical characterization of River Ganga at Haridwar, Uttarakhand. Water biology, (ISBN978-93-5056-888-0): 143-159.

Edmondson, W. T. 1959. Fresh water Biology. 2nd Edn., John Wiley and Sons, New York. p. 1248.

Joshi, B. D., Pathak, J. K., Singh, Y. N. Bisht, R. C. S. and Joshi, N. 1993. Phytoplankton production in the snow fed

\section{Conclusion}

Planktonic diversity exhibits a very important component of aquatic reservoir. In the present study an emphasis has been given to identify species of plankton and their relation with water quality parameters. Phytoplankton was observed as Chlorophyceae $>$ Bacillariophyceae > Cyanophyceae while zooplankton was observed as Rotifera $>$ Protozoa $>$ Cladocera $>$ copepod. Planktonic diversity and water quality was found strongly correlated with each other. During the present study the most pollution tolerant species of Oscillatoria, Euglena and Navicula were recorded. Among the zooplankton, Rotifers were good indicators of water quality. Rotifers of genus Brachionus and Keratella are abundant in water of the reservoir. Their occurrence in eutrophic water was well documented. We conclude that there are several reasons for the deterioration of the plankton diversity especially at Tumaria main canal. These findings will help in the future studies for bio monitoring of the Tumaria reservoir.

river Bhagirathi in the Garhwal Himalaya. Himalayan Journal of Environment and Zoology, 7: 60-63.

Khanna, D. R. and Bhutiani, R. 2005. Benthic fauna and its ecology of river Ganga from Rishikesh to Haridwar (Uttaranchal) India. Environment Conservation Journal, 6(1): 33-40.

Khanna, D. R., Malik, D. S. and Rana, D. S. 1998. Phytoplanktonic communities in relation to certain physico-chemical parameters of Ganga canal at Haridwar Himalayan Journal of Environment and Zoology, 12(2): 193-197.

Khanna, D. R., Rana, R. and Matta, G. 2011. Ecology of Fish Pond. Publishing House New Delhi: 176.

Khanna, D. R. and Bhutiani, R. 2007. Laboratory Manual of Water and Wastewater Analysis. Daya Publishing House New Delhi pp. 1-184.

Kumar, P and Shyam, R. G. 2018. Hydrobiological assessment of Tumaria reservoir, Kashipur (Udham Singh Nagar). Environment Conservation Journal, 19(3): 37-41.

Major, Y., Kifle, D., Niedrist, G. H. and Sommaruga, R. 2017. An isotopic analysis of the phytoplankton-zooplankton link in a highly eutrophic tropical reservoir dominated by cyanobacteria. Journal of Plankton Research, 39(2): 220231. 
Negi, R. K., Yadav, N. and Vishnoi, V. 2013. Phytoplankton diversity of some selected streams of Dehradun district of Uttarakhand state. Asian Journal of Biological and Life sciences, 1(4): 165-170.

Negi, V. and Pant, M. C. 1983. Analysis of Zooplankton community of lake Khurpatal (Kumaun Himalayas). Tropical Ecology, 24: 271-182.

Oriola, G. A. A. 2003. Zooplankton associations and Environmental factors in Ogupa and ona rivers. Nigeria. Revista de Biología Tropical, 51(2): 391-398.

Pathani, S. S. and Upadhyay, K. K. 2003. An inventory on Zooplankton, Zoobenthos and fish fauna in the River RamGanga (W) of Uttaranchal, India. Envis. Bulletin of Himalayan Ecology 14(2): 10.

Rao, K. R. 2017. Zooplankton diversity and seasonal variations in Thandava reservoir, Visakhapatnam, India.
International Journal of Aquaculture and Fishery Sciences, 5(1): 90-97.

Sharma, R. C. and Tiwari, V. 2018. Phytoplankton diversity in relation to physico-chemical environmental variables of Nachiketa Tal, Garhwal Himalaya. Biodiversity International Journal, 2(2): 102-107.

Singh, S. 2015. Analysis of Plankton Diversity and Density with Physico-Chemical Parameters of open Pond in Town Deeg (Bharatpur) Rajasthan, India. Asian Journal of Biological and Life sciences, 4(11): 6169.

Sivakumar, K. and Altaff, K. 2003. Ecological indices of freshwater copepods and Cladocerans from Dharmapuri district, Tamilnadu. Zoo's print, 19 (5): 1466-1468.

Summarwar, S. 2012. Studies on Plankton Diversity in Bisalpur Reservoir. International Journal of Life Sciences Biotechnology and Pharma Research, 1(4): 1-8. 